\title{
Procalcitonin levels and bacterial aetiology among COPD patients admitted to the ICU with severe pneumonia: a prospective cohort study
}

\author{
Cédric Daubin*1, Jean-Jacques Parienti ${ }^{2}$, Sabine Fradin ${ }^{3}$, Astrid Vabret ${ }^{4}$, \\ Michel Ramakers ${ }^{1}$, Nicolas Terzi ${ }^{1}$, François Freymuth ${ }^{4}$, Pierre Charbonneau ${ }^{1}$ \\ and Damien du Cheyron ${ }^{1}$
}

\begin{abstract}
Address: ${ }^{1 T h e}$ Department of Medical Intensive Care, Caen University Hospital, 14033 Caen Cedex, France, ${ }^{2}$ The Department of Infectious Diseases and Biostatistics and Clinical Research, Caen University Hospital, 14033 Caen Cedex, France, ${ }^{3}$ The Department of Biochemistry, Caen University Hospital, 14033 Caen Cedex, France and ${ }^{4}$ The Department of Virology, Caen University Hospital, 14033 Caen Cedex, France

Email: Cédric Daubin* - daubin-c@chu-caen.fr; Jean-Jacques Parienti - parienti-jj@chu-caen.fr; Sabine Fradin - fradin-s@chu-caen.fr; Astrid Vabret - vabret-a@chu-caen.fr; Michel Ramakers - ramakers-m@chu-caen.fr; Nicolas Terzi - terzi-n@chu-caen.fr;

François Freymuth - freymuth-f@chu-caen.fr; Pierre Charbonneau - charbonneau-p@chu-caen.fr; Damien du Cheyron - ducheyron-d@chucaen.fr

* Corresponding author
\end{abstract}

Published: 21 September 2009

BMC Infectious Diseases 2009, 9:157 doi:10.1186/1471-2334-9-157

This article is available from: http://www.biomedcentral.com/I47I-2334/9/157

(C) 2009 Daubin et al; licensee BioMed Central Ltd.

This is an Open Access article distributed under the terms of the Creative Commons Attribution License (http://creativecommons.org/licenses/by/2.0), which permits unrestricted use, distribution, and reproduction in any medium, provided the original work is properly cited.
Received: 19 March 2009

Accepted: 2I September 2009

\begin{abstract}
Background: Serum procalcitonin (PCT) is considered useful in predicting the likeliness of developing bacterial infections in emergency setting. In this study, we describe PCT levels overtime and their relationship with bacterial infection in chronic obstructive pulmonary disease (COPD) critically ill patients with pneumonia.

Methods: We conducted a prospective cohort study in an ICU of a University Hospital. All consecutive COPD patients admitted for pneumonia between September 2005 and September 2006 were included. Respiratory samples were tested for the presence of bacteria and viruses. Procalcitonin was sequentially assessed and patients classified according to the probability of the presence of a bacterial infection.

Results: Thirty four patients were included. The PCT levels were assessed in 32/34 patients, median values were: $0.493 \mu \mathrm{g} / \mathrm{L}$ [IQR, $0.13 \mathrm{I}$ to I.47I] at the time of admission, $0.724 \mu \mathrm{g} / \mathrm{L}$ [IQR, 0.167 to 2.646 ] at six hours, and $0.557 \mu \mathrm{g} / \mathrm{L}$ [IQR, 0.123 to 3.4 ] at 24 hours. The highest PCT (PCTmax) levels were less than $0.1 \mu \mathrm{g} / \mathrm{L}$ in $3 / 32(9 \%)$ patients and greater than $0.25 \mu \mathrm{g} / \mathrm{L}$ in $22 / 32(69 \%)$ patients, suggesting low and high probability of bacterial infection, respectively. Fifteen bacteria and five viruses were detected in 15/ $34(44 \%)$ patients. Bacteria were not detected in patients with PCTmax levels $<0.1 \mu \mathrm{g} / \mathrm{L}$. In contrast, bacteria were detected in $4 / 7$ (57\%) patients estimated unlikely to have a bacterial infection by PCT levels (PCTmax $>0.1$ and $<0.25 \mu \mathrm{g} / \mathrm{L}$ ).

Conclusion: Based on these results we suggest that a PCT level cut off $>0.1 \mu \mathrm{g} / \mathrm{L}$ may be more appropriate than $0.25 \mu \mathrm{g} / \mathrm{L}$ (previously proposed for non severe lower respiratory tract infection) to predict the probability of a bacterial infection in severe COPD patients with pneumonia. Further studies testing procalcitonin-based antibiotic strategies are needed in COPD patients with severe pneumonia.
\end{abstract}




\section{Background}

Severe pneumonia is a common cause of acute exacerbations of chronic obstructive pulmonary disease (AECOPD) [1]. In this setting, a prompt initiation of antibiotics is recommended [2,3]. However, bacterial etiology is only found in approximately $50 \%$ of cases $[1,4]$. Other pathogens, such as respiratory viruses, have been reported in severe AECOPD requiring ventilation $[5,6]$ and pneumonic AECOPD [1]. Moreover, in clinical practice, signs and symptoms of bacterial and viral lower respiratory tract infections widely overlap [7].

Procalcitonin (PCT) has been described as a marker of bacterial infection [8] and thus may help physicians to limit inadequate use of antibiotics [9-11]. We previously investigated the use of PCT in patients with AECOPD, without pneumonia, hospitalized in the ICU [12]. In this study, we assessed PCT levels overtime and their relationship with bacterial infection in chronic obstructive pulmonary disease (COPD) patients admitted to the ICU with severe pneumonia. In addition, we examined whether PCT thresholds predicting probability of bacterial infection previously reported [9-11] could be efficient in this specific population.

\section{Methods \\ Patients}

We conducted a monocentric prospective cohort study. All consecutive COPD patients with suspected lower respiratory tract infection admitted to the medical intensive care unit of the University Hospital of Caen between September 2005 and September 2006 were assessed for eligibility. Only those with infiltrates present on initial chest radiographs at admission to ICU and suspected for acute community-acquired pneumonia were included.

\section{Definition}

We defined COPD according to the Global Initiative for Chronic Obstructive Lung Disease Guidelines (GOLD) 2005 http://www.goldcopd.com. Pneumonic AECOPD was defined as a new infiltrate on chest radiograph with features of lower respiratory tract infection in COPD patients $[1,11,12]$. We used the pneumonia severity index (PSI) to estimate severity [13]. A systematic search for bacteria with standard methods and for viruses with sensitive methods (i.e., PCR and RT-PCR methods), as reported elsewhere $[6,12,14-16]$ were performed. Briefly, sputum or tracheal aspirates were bacteriologically processed if less than $1 \%$ of the observed field contained squamous epithelial cells and more than 25 neutrophils were observed [17]. Pneumonia was considered bacteriologically confirmed when at least one of the following criteria were present: pathogen concentration greater than $10^{5}$ $\mathrm{cfu} / \mathrm{mL}$ in tracheobronchial aspirations or sputum samples; blood culture positive for a bacterial pathogen in the absence of an extrapulmonary focus [17-19]. In addition, a serological diagnostic for antibodies to Legionella pneumophila was performed by indirect immunofluorescence, associated with a detection of Legionella pneumophila serogroup 1 antigen in urine samples in all patients.

\section{Study design}

The ethical board decided approval was not necessary given the observational nature of the study. Accordingly, no informed consent was obtained from the patients. At baseline, COPD severity, according to GOLD criteria, other comorbidities, and clinical and biological variables were recorded [12]. All patients were treated according to the recommendations of the French Consensus Conference [3] (i.e., an antibiotic treatment is recommended in severe pneumonia and severe exacerbation of COPD patients requiring admission in ICU).

\section{Measurement of serum procalcitonin}

Procalcitonin (PCT) assessment followed standard methods described elsewhere [12]. The circulating levels of PCT were sequentially assessed at ICU admission (PCT-H0), after six hours (PCT-H6), and after twenty fours (PCTH24) hours in ICU. All blood samples were analyzed at the end of the study period. PCT was measured using a sensitive immunoassay (Kryptor PCT, Brahms, Hennigsdorf, Germany) with a functional assay sensitivity of $0.06 \mu \mathrm{g} / \mathrm{L}$, about fourfold above mean normal levels [20]. Patients were classified into three groups based on probability of bacterial infection according to the highest procalcitonin level measured (PCTmax). As previously reported [9-11], the groups were: group 1, PCTmax $<0.1$ $\mu \mathrm{g} / \mathrm{L}$ indicating an a low probability of a bacterial infection; group 2, PCTmax $>0.1$ and $<0.25 \mu \mathrm{g} / \mathrm{L}$ indicating an unlikely or possible bacterial infection infection; and group 3, PCTmax $>0.25 \mu \mathrm{g} / \mathrm{L}$ indicating a high probability of bacterial infection.

\section{Statistical analysis}

Quantitative and qualitative data were expressed as means (+/- SD), or median (interquartile range, IQR) and percentage (with their 95\% confidence intervals (CI) based on normal approximation), respectively. Categorical variables were compared using the chi-square or Fischer's exact test, as appropriate. Quantitative variables were compared using the Student $t$-test or the Mann-Whitney non parametric test, as appropriate. The level of significance was set at 0.05 and all tests were two-sided. We used EPI-INFO version 6.04 dfr (EPI-INFO, CDC, Atlanta, GA) for data collection, and EPI-INFO and SAS version 9.1 (SAS Institute Inc, Cary, NC) for data analysis. 


\section{Results}

\section{Patients and baseline characteristics}

During the study period, 80 COPD patients with suspected lower respiratory tract infection were admitted to the ICU, 34 had pneumonia. Baseline characteristics of the pneumonic AECOPD patients are shown in Table 1.
Twenty three patients (68\%) had severe or very severe COPD. During the previous 30-day period, antibiotic or oral steroid therapy for exacerbations of COPD was reported by 7 and 8 patients, respectively. Eleven patients had received antibiotics within the 24 hours preceding ICU admission. With the exception of 4 patients, all had a

Table I: Baseline characteristics of all patients and according to the maximum procalcitonin levels measured (PCTmax)

\begin{tabular}{|c|c|c|c|c|}
\hline Characteristics & $\begin{array}{c}\text { All } \\
\mathrm{n}=34^{*}\end{array}$ & $\begin{array}{c}P C T<0.1 \\
n=3\end{array}$ & $\begin{array}{c}0.1<\text { PCT }<0.25 \\
n=7\end{array}$ & $\begin{array}{c}\mathrm{PCT}>0.25 \\
n=22\end{array}$ \\
\hline Age, $y r$ & $70 \pm 10$ & $71 \pm 10$ & $71 \pm 10$ & $69 \pm 10$ \\
\hline Male sex, no.(\%) & $28(82)$ & $2(66)$ & $6(86)$ & $18(82)$ \\
\hline SAPS II score & $37[20-50]$ & $27[23-30]$ & 31 [24-44] & 40 [34-62] \\
\hline LOD score & $6[4-10]$ & $6[4-10]$ & $6[411]$ & $6[4-10]$ \\
\hline \multicolumn{5}{|l|}{ Comorbidities, no (\%) } \\
\hline Current smokers, & II (32) & 0 & $4(57)$ & $7(32)$ \\
\hline Chronic alcohol abuse & $8(24)$ & $2(66)$ & $\mathrm{I}(14)$ & $4(18)$ \\
\hline Obesity & $12(35)$ & $3(100)$ & $2(29)$ & $5(23)$ \\
\hline Coronary artery disease & $14(4 \mid)$ & $I(33)$ & $3(43)$ & $9(4 I)$ \\
\hline Hypertensive heart disease & $17(50)$ & $\mathrm{I}(33)$ & $2(29)$ & $12(55)$ \\
\hline Congestive heart disease & $9(26)$ & $\mathrm{I}(33)$ & 0 & $8(36)$ \\
\hline Diabetes mellitus & $13(38)$ & 0 & $3(43)$ & $8(36)$ \\
\hline Chronic pseudomonas colonisation, no (\%) & $4(12)$ & 0 & $2(29)$ & $2(9)$ \\
\hline Antibiotics in $24 \mathrm{H}$ prior ICU admission $\pi$, no (\%) & $11(32)$ & 0 & $2(29)$ & $8(36)$ \\
\hline \multicolumn{5}{|l|}{ During the previous 30-day period 1 Tा } \\
\hline Antibiotics for AECOPD & $7(20)$ & 0 & $2(29)$ & $5(23)$ \\
\hline Oral steroid therapy for AECOPD & $8(24)$ & $\mathrm{I}(33)$ & $3(43)$ & $5(23)$ \\
\hline \multicolumn{5}{|l|}{ Severity of COPD, no (\%) } \\
\hline GOLD stage I (mild) & $2(6)$ & 0 & 0 & $2(9)$ \\
\hline GOLD stage II (moderate) & $9(26)$ & $\mathrm{I}(33)$ & 0 & $6(27)$ \\
\hline GOLD stage III (sever) & $3(9)$ & 0 & 0 & $3(14)$ \\
\hline GOLD stage IV (very sever) & 20(59) & $2(66)$ & $7(100)$ & $\mathrm{II}(50)$ \\
\hline Home oxygen, no (\%) & $18(53)$ & $2(66)$ & $5(7 I)$ & $11(50)$ \\
\hline Home non-invasive ventilation, no (\%) & $6(18)$ & $\mathrm{I}(33)$ & $2(28)$ & $3(14)$ \\
\hline Oral or inhaled steroid, no (\%) & $19(56)$ & $2(66)$ & $6(85)$ & $10(45)$ \\
\hline \multicolumn{5}{|l|}{ Examination at ICU admission, no (\%) } \\
\hline Dyspnea & $34(100)$ & $3(100)$ & $7(100)$ & $22(100)$ \\
\hline Cough & $\mathrm{II}(32)$ & $\mathrm{I}(33)$ & $3(43)$ & $7(32)$ \\
\hline Sputum & $16(47)$ & $2(66)$ & $3(43)$ & $11(50)$ \\
\hline Rales & $15(44)$ & $\mathrm{I}(33)$ & $\mathrm{I}(14)$ & $12(55)$ \\
\hline Wheezing & $16(47)$ & $2(66)$ & $6(86)$ & $7(32)$ \\
\hline Body temperature, ${ }^{\circ} \mathrm{C}$ & $37.3 \pm 1.2$ & $37.0 \pm 0.7$ & $36.5 \pm 0.7$ & $37.7 \pm 1.3$ \\
\hline Leucocytes count $(\times 109 / L)$ & $13.7 \pm 6.4$ & $\mathrm{II} .2 \pm 0.4$ & $12.5 \pm 3.4$ & $14.9 \pm 7.4$ \\
\hline \multicolumn{5}{|l|}{ Pneumonia severity index (PSI) } \\
\hline PSI I, II, III & $4(I I)$ & $I(33)$ & $2(28)$ & $I(5)$ \\
\hline PSI IV & $14(42)$ & $\mathrm{I}(33)$ & $4(57)$ & $8(36)$ \\
\hline PSI V & $16(47)$ & $I(33)$ & $I(14)$ & $13(59)$ \\
\hline
\end{tabular}

Values are given as No.(\%), median [25\%-75\% interquartile range], or mean \pm standard deviation

* Levels of procalcitonin (PCT) were assessed in $32 / 34$ patients. PCT is given in $\mu \mathrm{g} / \mathrm{L}$

$\pi$ One patient receiving antibiotic in $24 \mathrm{~h}$ prior ICU was not assessed for PCT levels

ITा Patients treated with antibiotic or oral steroid during the previous 30-day period for exacerbation of COPD were exclusive of those receiving antibiotic in $24 \mathrm{~h}$ prior ICU 
severe pneumonia (PSI class IV and V). All patients required ventilator support: non invasive ventilation (NIV) in $23(68 \%)$ patients and invasive mechanical ventilation in $20(58 \%)$ patients, 9 of whom received invasive mechanical ventilation after NIV failure. All patients received antibiotics and inhaled steroids and 18 (53\%) systemic steroids. The mean length of ICU stay was $29 \pm$ 31 days. The mean length of non-invasive ventilation, invasive mechanical ventilation, and ventilation-free days during the ICU stay were $2.85 \pm 5.1$ days, $17.8 \pm 31.1$ days, and $2.56 \pm 2.34$ days, respectively. Fourteen patients developed septic shock, nine during the first hours following ICU admission and five during their ICU stay. Six patients developed ventilator-associated pneumonia. Twenty two patients were discharged from the hospital. Twelve patients died, eight from septic shock, three from COPD-related respiratory failure, and one from malignant bronchospasm complicated with cardiac arrest.

\section{PCT measurements and clinical correlates}

The median [25\%-75\% IQR] PCT levels were as follows: at admission PCT-H0 was $0.493 \mu \mathrm{g} / \mathrm{L}$ [0.131-1.471], PCTH6 was $0.724 \mu \mathrm{g} / \mathrm{L}[0.167-2.646]$, and PCT-H24 was $0.557 \mu \mathrm{g} / \mathrm{L}[0.123-3.4]$.

PCT levels were not different in patients who had received antibiotics within the month or 24 hours prior to ICU admission, compared to antibiotic-naive patients (PCTH0 0.695 $\mu \mathrm{g} / \mathrm{L}[0.202-1.139]$ vs $0.470 \mu \mathrm{g} / \mathrm{L}[0.088-1.471]$, $p=0.73$ and PCT-HO $0.942 \mu \mathrm{g} / \mathrm{L}[0.202-22.110]$ vs 0.438 $\mu \mathrm{g} / \mathrm{L}$ [0.088-0.902], $p=0.22$, respectively). In addition, steroids prior to ICU admission did not influence PCT levels $(p=0.76)$. PCT-H0 was significantly higher when abnormal breath sounds or rales were present (PCT-H0 $1.661 \mu \mathrm{g} / \mathrm{L}[0.745-26.83]$ vs $0.207 \mu \mathrm{g} / \mathrm{L}$ [0.086-0.470], $p=$ $0.0005)$ and when fever $>38^{\circ} \mathrm{C}$ was present; PCT-H0 $1.495 \mu \mathrm{g} / \mathrm{L}$ [0.828-56.48] vs $0.272 \mu \mathrm{g} / \mathrm{L}$ [0.087-0.902], $p=$ $0.0 .05)$. No association was found between PCT-HO levels and the presence or absence of sputum and cough.

The PCTmax was $<0.1 \mu \mathrm{g} / \mathrm{L}$ in $3 / 32$ patients $(9 \%)$, between 0.1 and $0.25 \mu \mathrm{g} / \mathrm{L}$ in $7 / 32$ patients $(22 \%)$, and > $0.25 \mu \mathrm{g} / \mathrm{L}$ in $22 / 32$ patients $(69 \%)$, including 20 patients with PCTmax $>0.5 \mu \mathrm{g} / \mathrm{L}$. There were no associations between PCTmax levels $>0.25 \mu \mathrm{g} / \mathrm{L}$ and severity of COPD $(p=0.21)$, Simplified Acute Physiology Score type II (SAPSII) $(p=0.15)$, Logistic Organ Dysfonction (LOD) $(p=$ $0.29)$, and PSI $(p=0.08)$.

\section{PCTmax levels and bacterial findings}

Figure 1 depicts bacterial findings according to PCTmax levels. The dynamics of PCT measurements and bacterial findings are shown Figure 2. Fifteen (44\%) patients had microbiologically-confirmed pneumonia. Fifteen bacteria (4 Pseudomonas aeruginosa, 3 Haemophilus influenzae, 3
Streptoccocus species, 3 Methicillin-resistant Staphyloccocus aureus, 1 Serratia species, and 1 Fusibacterium nucleatum) and 5 viruses ( 3 rhinovirus, 1 human metapneumovirus, and 1 respiratory syncitial virus) were detected. A co-infection was detected in 3 cases (rhinovirus and Streptoccocus, rhinovirus and Haemophilus influenzae, and rhinovirus and Fusibacterium nucleatum). Seven patients cross over between PCT groups over time (Figure 2). No bacteria were detected in patients with PCTmax level $<0.1 \mu \mathrm{g} / \mathrm{L}$. In contrast, bacteria were detected in more than half the patients estimated to have an unlikely bacterial infection (PCTmax $>0.1$ and $<0.25 \mu \mathrm{g} / \mathrm{L}$ ).

\section{Discussion}

Our study examined microbiological findings and PCT levels in critically ill COPD patients admitted for pneumonia. To our knowledge, this has not been addressed in the specific setting of the ICU. In agreement with previous report [11], PCT level $<0.1 \mu \mathrm{g} / \mathrm{L}$ could indicate a low probability of bacterial infection in approximately $10 \%$ of patients (3/32). In contrast, bacteria were detected in more than half the patients (4/7) with PCT levels suggesting an unlikely or possible bacterial infection (PCTmax between 0.1 and $0.25 \mu \mathrm{g} / \mathrm{L}$ ), as previously defined outside the ICU [9-11]. Therefore, a PCT cut off below $0.25 \mu \mathrm{g} / \mathrm{L}$ for antibiotic use may not be appropriate for severe pneumonia patients with COPD admitted to the ICU.

We found a median PCT level of $0.493 \mu \mathrm{g} / \mathrm{L}$ [0.131-1.471] in COPD patients admitted to the ICU for pneumonia, this finding is consistent with previous studies focusing on community-acquired pneumonia (CAP) [11,21]. However, in these two large prospective cohorts focusing on CAP, less than $25 \%$ of patients had COPD and less than $10 \%$ were admitted to the ICU. In previous reports, PCT levels were not different between patients pre-treated with antibiotics and antibiotic-naive patients [10,11], a finding confirmed by our study. In contrast to previous reports, we found an association between PCT levels and clinical symptoms (fever and abnormal breath sounds or rales).

The distribution of patients according to PCTmax levels (ie $<0.1 \mu \mathrm{g} / \mathrm{L}, 0.1$ to $0.25 \mu \mathrm{g} / \mathrm{L}$, and $>0.25 \mu \mathrm{g} / \mathrm{L}$ ) was similar to that previously reported by Christ-Crain et al [11]. In patients $(10 \%)$ with PCTmax levels $<0.1 \mu \mathrm{g} / \mathrm{L}$, bacteria were not detected, suggesting antibiotics may be unnecessary in this subgroup. In contrast, bacteria were detected in more than half the patients with PCT levels suggesting an unlikely or possible bacterial infection (PCTmax $>0.1$ and $<0.25 \mu \mathrm{g} / \mathrm{L})$. This result suggests a PCT level cut-off $>$ $0.1 \mu \mathrm{g} / \mathrm{L}$, rather than $>0.25 \mu \mathrm{g} / \mathrm{L}$ (proposed for non severe pneumonia [11]), may be more appropriate for initiating antibiotics in a PCT based antibiotic strategy in critically 


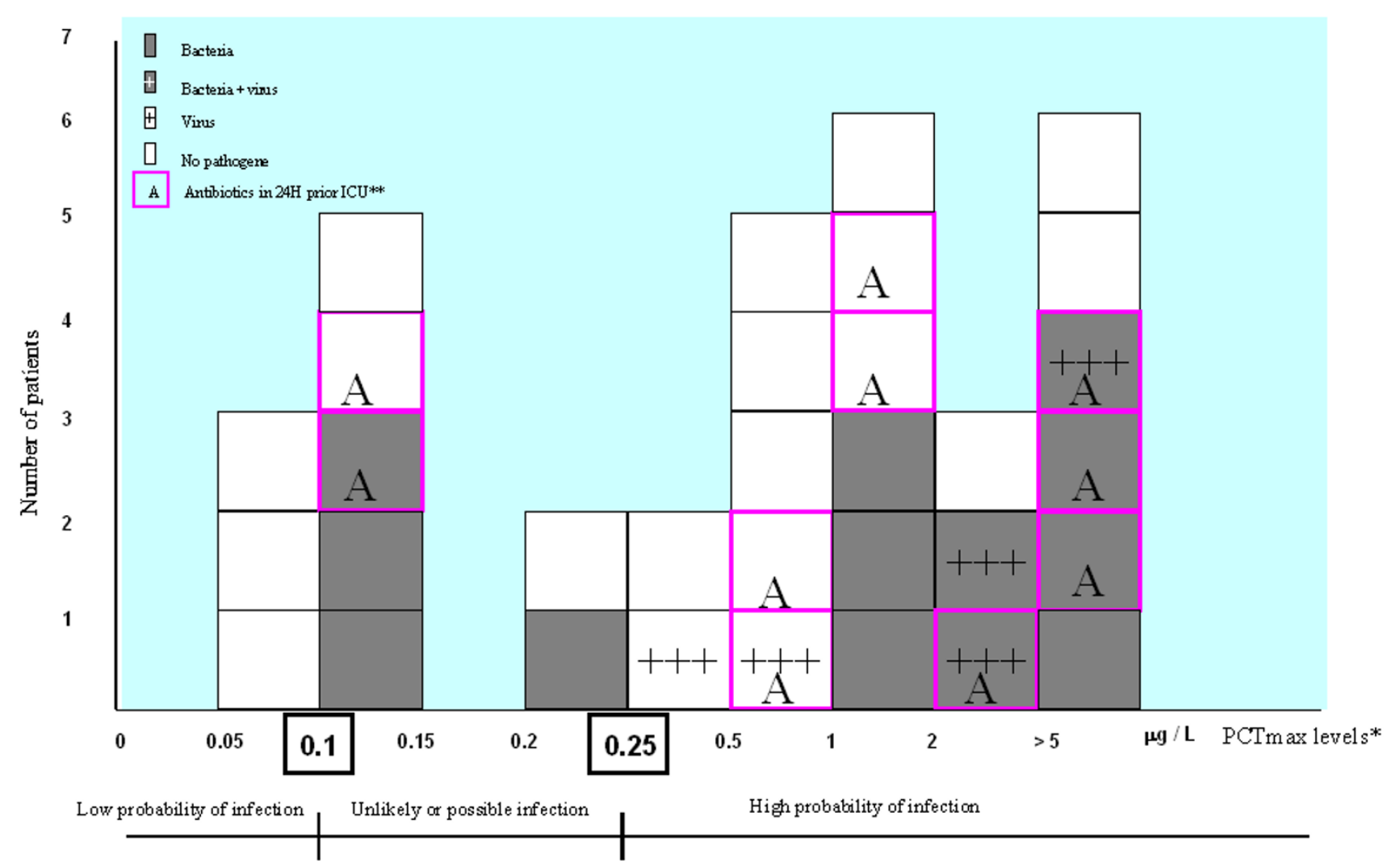

Figure I

Distribution of the highest procalcitonin level measurements (PCTmax) and microorganism findings in chronic obstructive pulmonary disease (COPD) patients with pneumonia. Also shown is the probability of bacterial infection according to procalcitonin (PCT) levels, as previously reported by Christ-Crain (I I). * Procalcitonin (PCT) levels were not assessed in 2 patients. ** One patient receiving antibiotic in $24 \mathrm{~h}$ prior ICU was not assessed for PCT levels.

ill COPD patients with pneumonia. Such a study, however, remains to be conducted.

In addition, this study confirms the importance of a sequential PCT levels assessment to predict probability of bacterial infection specifically when the first measurement is low (i.e., PCT $<0.1 \mu \mathrm{g} / \mathrm{L}$ ). Indeed, three from five patients crossing over from PCT group $<0.1 \mu \mathrm{g} / \mathrm{L}$ to PCT group 0.1-0.25 $\mu \mathrm{g} / \mathrm{L}$ over time, had bacteriologically documented pneumonia. This point should have important implications for furthers studies assessing procalcitoninbased antibiotic strategies in this setting.

We are aware of the limitations of our study, which include the monocentric design and small sample size. In addition, a prior ICU admission antibiotic treatment in a subset of patients may have affected the results of microbiological examinations. However, all patients pre-treated with antibiotics had PCT levels higher than $0.25 \mu \mathrm{g} / \mathrm{L}$ (except two in PCT group 0.1-0.25 $\mathrm{gg} / \mathrm{L}$ ) indicating a high probability of the presence of bacterial infection. Strengths of the study include the dynamic measurement of PCT along with the systematic search for bacteria in a specific population. For this reason, we believe this study adds useful information about PCT levels in COPD patients with severe pneumonia requiring admission to ICU and the likelihood of bacterial infection.

\section{Conclusion}

This study reports that less than $10 \%$ of COPD patients suspected of severe pneumonia had PCT levels lower than $0.1 \mu \mathrm{g} / \mathrm{L}$ suggesting a low probability of a bacterial infection and that a subset of patient with PCT levels between 0.1 and $0.25 \mu \mathrm{g} / \mathrm{L}$ (range previously reported as indicating an unlikely or possible bacterial infection [9-11]) had a documented bacterial infection. Based on these results we hypothesize that a PCT level cut off $>0.1 \mu \mathrm{g} / \mathrm{L}$ may be more appropriate than 0.25 (previously proposed for non severe lower respiratory tract infection [9-11] to predict the probability of a bacterial infection in severe COPD 


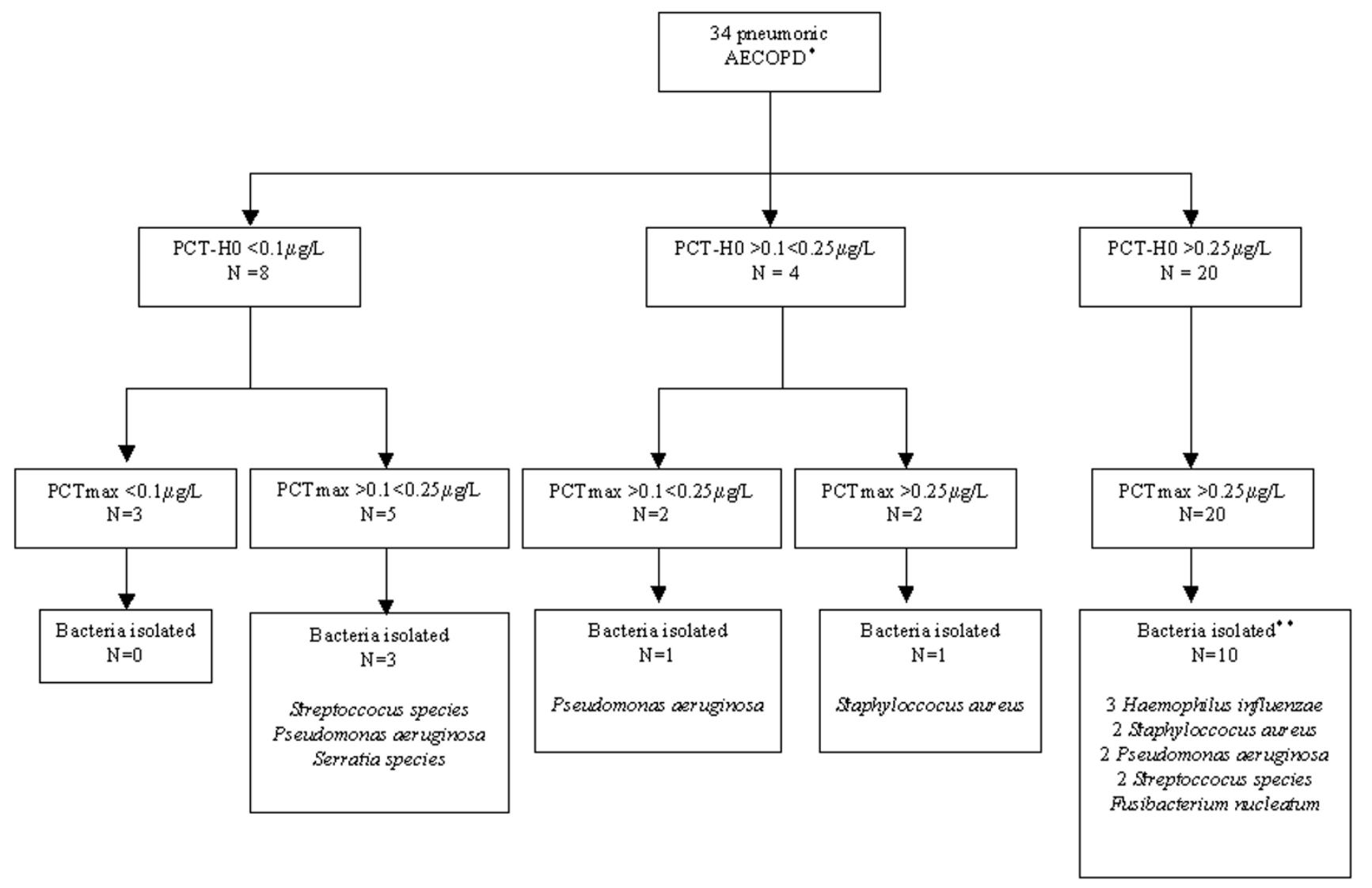

Figure 2

Dynamics of PCT measurements and bacterial findings. * Procalcitonin (PCT) levels were not assessed in 2 patients. ** A bacterial co-infection was detected in 2 patients.

patients with pneumonia in a procalcitonin-based antibiotic strategy. However, in clinical practice, a such procalcitonin-based antibiotic strategy using the PCT threshold of $0.1 \mu \mathrm{g} / \mathrm{L}$ should have only a limited impact on the decision to initiate antibiotics in this setting. Further studies are necessary to assess the capability of procalcitonin guidance to shorten antibiotic duration in critically ill COPD patients with pneumonia.

\section{Abbreviations}

AECOPD: acute exacerbation of chronic obstructive pulmonary disease; APACHE II: acute physiology and chronic health evaluation type II; ICU: medical intensive care unit; LOD: logistic organ dysfunction system; PCR: polymerase chain reaction; PSI: pneumonia severity index; SAPS II: simplified acute physiology score II.

\section{Competing interests}

The authors declare that they have no competing interests.

\section{Authors' contributions}

$\mathrm{CD}$ and MR initiated the study, the design, and the experimental protocol. SF performed the PCT measurements. $\mathrm{AV}$ and FF performed the virologic assessments. CD and JJP performed the statistical analysis and were involved in the interpretation of the results. CD wrote the manuscript, and JJP, MR, and DDC helped to draft the manuscript. DDC, MR, NT, and PC contributed to the conception and design of the study and revision of the manuscript. All authors read and approved the final manuscript.

\section{Acknowledgements}

The authors want to thank the nursing staff of the Lemière and Babinski units for their important contributions during the conduction of this study. The authors thank BRAHMS (the manufacturer of procalcitonin assay) for providing assay materials. This study was funded by an academic unrestricted grant from the Caen Côte de Nacre University hospital.

\section{References}

I. Lieberman D, Lieberman D, Gelfer Y, Varshavsky R, Dvoskin B, Leinonen M, Friedman MG: Pneumonic vs nonpneumonic acute exacerbations of COPD. Chest 2002, I 22:1264-70. 
2. Woodhead M, Blasi F, Ewig S, Huchon G, leven M, Ortqvist A, Schaberg T, Torres A, Heijden G van der, Verheij TJ, European Respiratory Society: Guidelines for the management of adult lower respiratory tract infections. Eur Respir J 2005, 26: I I38-I I80.

3. Société de Pathologie Infectieuse de Langue Française: [15th consensus conference about management of lower respiratory tract infections in immunocompetent adult]. Med Mal Infect 2006, 36:235-244.

4. Torres A, Dorca J, Zalacaín R, Bello S, El-Ebiary M, Molinos L, Arévalo M, Blanquer J, Celis R, Iriberri M, Prats E, Fernández R, Irigaray R, Serra J: Community-acquired pneumonia in chronic obstructive pulmonary disease: a Spanish multicenter study. $\mathrm{Am} J$ Respir Crit Care Med 1996, 154:1456-6I.

5. Cameron RJ, de Wit D, Welsh TN, Ferguson J, Grissell TV, Rye PJ: Virus infection in exacerbations of chronic obstructive pulmonary disease requiring ventilation. Intensive Care Med 2006, 32: 1022-1029.

6. Daubin C, Parienti JJ, Vincent S, Vabret A, du Cheyron D, Ramakers $M$, Freymuth F, Charbonneau P: Epidemiology and clinical outcome of virus-positive respiratory samples in ventilated patients: a prospective cohort study. Crit Care 2006, I0:R I42.

7. Halm EA, Teirstein AS: Clinical practice. Management of community-acquired pneumonia. N Engl J Med 2002, 347:2039-45.

8. Simon L, Gauvin F, Amre DK, Saint-Louis P, Lacroix J: Serum procalcitonin and C-reactive protein levels as markers of bacterial infection: a systematic review and meta-analysis. Clin Infect Dis 2004, 39:206-217.

9. Christ-Crain M, Jaccard-Stolz D, Bingisser R, Gencay MM, Huber PR, Tamm M, Müller B: Effect of procalcitonin-guided treatment on antibiotic use and outcome in lower respiratory tract infections: cluster-randomised, single-blinded intervention trial. Lancet 2004, 363:600-607.

10. Stolz D, Christ-Crain M, Bingisser R, Leuppi J, Miedinger D, Müller C, Huber P, Müller B, Tamm M: Antibiotic treatment of exacerbations of COPD: a randomized, controlled trial comparing procalcitonin-guidance with standard therapy. Chest 2007, |31:9-19.

II. Christ-Crain M, Stolz D, Bingisser R, Müller C, Miedinger D, Huber PR, Zimmerli W, Harbarth S, Tamm M, Müller B: Procalcitonin guidance of antibiotic therapy in community-acquired pneumonia: a randomized trial. Am J Respir Crit Care Med 2006, 174:84-93.

12. Daubin C, Parienti JJ, Vabret A, Ramakers M, Fradin S, Terzi N, Freymuth $F$, Charbonneau $P$, du Cheyron D: Procalcitonin levels in acute exacerbation of COPD admitted in ICU: a prospective cohort study. BMC Infect Dis 2008, 8: 145 .

13. Fine MJ, Auble TE, Yealy DM, Hanusa BH, Weissfeld LA, Singer DE, Coley CM, Marrie TJ, Kapoor WN: A prediction rule to identify low-risk patients with community-acquired pneumonia. $\mathrm{N}$ Engl J Med 1997, 336:243-50.

14. Daubin C, Vincent S, Vabret A, du Cheyron D, Parienti JJ, Ramakers $M$, Freymuth F, Charbonneau P: Nosocomial viral ventilatorassociated pneumonia in the intensive care unit: a prospective cohort study. Intensive Care Med 2005, 3 I: I I I6-I I 22.

15. Bellau-Pujol S, Vabret A, Legrand L, Dina J, Gouarin S, Petitjean-Lecherbonnier, Pozzetto B, Ginevra C, Freymuth F: Development of three multiplex RT-PCR assays for the detection of $\mathbf{I} 2$ respiratory RNA viruses. J Virol Methods 2005, 1 26:53-63.

16. Freymuth F, Vabret A, Rozenberg F, Dina J, Petitjean J, Gouarin S, Legrand L, Corbet S, Brouard J, Lebon P: Replication of respiratory viruses, particularly influenza virus, rhinovirus, and coronavirus in $\mathrm{HuH7}$ hepatocarcinoma cell line. Med Virol 2005, 77:295-30I.

17. Murray PR, Washington JA: Microscopic and bacteriologic analysis of expectorated sputum. Mayo Clin Proc 1975, 50:339-344.

18. Soler N, Torres A, Ewig S, Gonzalez J, Celis R, El-Ebiary M, Hernandez $C$, Rodriguez-Roisin R: Bronchial microbial patterns in severe exacerbations of chronic obstructive pulmonary disease (COPD) requiring mechanical ventilation. Am J Respir Crit Care Med 1998, 157:|498-505.

19. Leroy O, Bosquet C, Vandenbussche C, Coffinier C, Georges H, Guery B, Alfandary S, Thevenin D, Beaucaire G: CommunityAcquired Pneumonia in the Intensive Care Unit: Epidemiological and prognosis data in Older People. J Am Geriart Soc 1999, 47:539-546.
20. Nylen E, Muller B, Becker KL, Snider R: The future diagnostic role of procalcitonin levels: the need for improved sensitivity. Clin Infect Dis 2003, 36:823-824.

2I. Masiá M, Gutiérrez F, Shum C, Padilla S, Navarro JC, Flores E, Hernández I: Usefulness of procalcitonin levels in communityacquired pneumonia according to the patients outcome research team pneumonia severity index. Chest 2005, 1 28:2223-9.

\section{Pre-publication history}

The pre-publication history for this paper can be accessed here:

\section{http://www.biomedcentral.com/1471-2334/9/157/pre} pub
Publish with Bio Med Central and every scientist can read your work free of charge

"BioMed Central will be the most significant development for disseminating the results of biomedical research in our lifetime. "

Sir Paul Nurse, Cancer Research UK

Your research papers will be:

- available free of charge to the entire biomedical community

- peer reviewed and published immediately upon acceptance

- cited in PubMed and archived on PubMed Central

- yours - you keep the copyright 